Available online at GSC Online Press Directory

GSC Biological and Pharmaceutical Sciences

e-ISSN: 2581-3250, CODEN (USA): GBPSC2

Journal homepage: https://www.gsconlinepress.com/journals/gscbps

(RESEARCH ARTICLE)

\title{
Phytochemical, antibacterial and free radical scavenging activities of a local antimalaria tea from Nigeria
}

\author{
Ufuoma Oghenejoboh ${ }^{1, *}$, Mukaram Akintunde Adeniyi-Akee ${ }^{2}$, Medi Ashioma ${ }^{1}$, Sunday Kunle Ogundairo ${ }^{1}$ \\ and Adenike Mary Olowolagba ${ }^{1}$ \\ ${ }^{1}$ Department of Chemistry University of Ibadan, Ibadan, Nigeria. \\ ${ }^{2}$ Department of Pharmaceutical Chemistry, College of Pharmacy, Igbinedion University, Okada, Benin City, Nigeria.
}

Publication history: Received on 07 July 2020; revised on 03 August 2020; accepted on 05 August 2020

Article DOI: https://doi.org/10.30574/gscbps.2020.12.2.0213

\begin{abstract}
Malaria is a reoccurring disease which affects about 296 million people globally. In countries where the people are overly attached to their culture like Nigeria, most of the population depends on local antimalaria remedies. One of such remedy is a tea of Citrus aurantifolia (leaves and peels), Psidium guajava (leaves) and Ocimum gratissimum (scent leaf) in alcohol. This study was aimed at determining the phytochemical, antibacterial and free radical scavenging activity of the methanol extract of this antimalaria tea, in order to determine the effect of its consumption on the human body. The phytochemical screening results showed the presence of compounds such as flavonoids, phenol, alkaloids and terpenoids amongst others. The extract also showed good antibacterial activity against $S$. aureus. The antioxidant activity results indicated that the lowest dose $(0.25 \mathrm{mg} / \mathrm{mL})$ of the tea had moderate antioxidant activity $(62 \%)$ as compared with that of the standard antioxidant used. The highest dose level on the other hand had a very poor antioxidant activity (-7\%). The results indicates that though consumption of the antimalaria tea may reduce the microbial load of $S$ aureus in the body, excessive consumption of the antimalaria tea could lead to long term neurological or cell damage in the human body because of the ability of the tea to generate free radicals when taken in high concentration.
\end{abstract}

\section{Keywords: Antimalaria; Antioxidant; Ocimum gratissimum; Psidium guajava; Citrus aurantifolia}

\section{Introduction}

Malaria is a reoccurring disease which affects about 296 million people globally. It is distributed mostly through the tropics and subtropics [1]. In Nigeria Plasmodium falciparum is one of the parasites responsible for malaria infection [2]. In the past chloroquine was an effective drug for the treatment of malaria, but in recent years the development of resistance by the parasites has led to the development of drug combination therapies. Antimalaria combination therapy (ACT) is not only practiced in modern medicine but also practiced in traditional medicine, because it is believed that the combination produces rapid results and helps to slow down the development of drug resistance [3]. Various traditional medicinal plants have been reported to be used in combination for the treatment of malaria $[4,5]$.

In developing countries like Nigeria most of the population prefers using medicinal plants singly or in combination for the treatment of various diseases, this could be due to an attachment of the people to their culture or a lack of access to modern medicine which in most cases is associated with poverty. The preference for traditional medicine could also be born from the fact that the medicinal plants are easily accessible, efficient and safe [6]. Generally medicinal plants contain numerous compounds called secondary metabolites which can act as sources of potential drugs for the management of diseases [7].

\footnotetext{
* Corresponding author: Oghenejoboh Ufuoma
} 
A combination of Citrus aurantifolia (key lime) leaves and peels, Psidium guajava leaves and Ocimum gratissimum (scent leaves) in either alcohol or water is a common local remedy consumed in southwestern Nigeria for the treatment of malaria [8] Citrus aurantifolia is a popular species in the citrus family which is mostly used as an additive in food, drinks and deserts. It is an essential part of many herbal preparations in Nigeria [9]. Studies have shown that treatment of malaria with lime juice in addition with an appropriate antimalarial drug results in complete clearance of malarial parasites [10]. Psidium guajava is a plant native to Mexico, but has naturalized across West Africa [11]. It is mainly used as an anti-diarrheal agent; it is also used in reducing fever a major symptom of malaria [12]. Ocimum gratissimum is a plant of the Lamiaceae family that is cultivated worldwide for its medicinal and culinary uses [13]. The leaves of the plant are used to prevent mosquito bites; this could be probably due to the presence of thymol which is the major component of the leaves [14].

Various studies have established the fact that the individual plants have antimalaria activity and can prevent the generation of free radicals because of their antioxidants activities [15 - 19]. This present study is aimed at determining the chemical composition, antioxidant activity and antibacterial activity of a formulation combining the peels and leaves of Citrus aurantifolia, Psidium guajava leaves and Ocimum gratissimum leaves in order to determine the effect of its consumption on the human body.

\section{Material and methods}

Leaves of citrus aurantifolia, Psidium guajava and Ocimum gratissimum were obtained from the Botanical garden of the University of Ibadan, and The Polythenic, Ibadan, Nigeria, while the peels were gotten from fresh mature fruits bought in a local market in Ibadan, Oyo State. The fruits and leaves were washed free of sand and other impurities with distilled water. The rinds of healthy fruits of Citrus aurantifolia were peeled off with a knife. The peels and all other plant parts were air dried for 28 days and combined to make up 816g. The combination was extracted with methanol as solvent. The phytochemical investigation on the extract was done following the methods described by Harbone J. B. [20].

\subsection{Antioxidant Activity}

The antioxidant activity of the extracts was determined using the Diphenyl picryl hydrazine method (DPPH) method (2, 2-dipheny-1-picryl hydrazine) as described by Mensor et al. [21], with some modifications [22]. Three different concentrations of the extracts were prepared $(1.0,0.5,0.25 \mathrm{mg} / \mathrm{ml})$. Butylated Hydroxyl Anisole and vitamin $\mathrm{C}$ were used as the reference standard antioxidant. Absorbance measurement was taken at $517 \mathrm{~nm}$ using spectrumlab S22PC visible spectrometer with model No 721S.

\subsection{Antibacterial Activity}

Environmental isolates of Klebsiella pneumonia were obtained from the Department of Microbiology, University of Ibadan while clinical isolates of Klebsiella pneumonia, Escherichia coli, Pseudomonas aeruginosa and Staphylococcus aureus were obtained from Adeoyo State Hospital, Ibadan. Confirmatory test were carried out on them. Gram staining and biochemical test (Catalase, oxidase, coagulase, indole test) were done on each of the organisms. All organisms were sub-cultured to obtain a pure culture on Nutrient agar and maintained on agar slant and kept in a refrigerator until use. Analysis was carried out at the Department of Microbiology, University of Ibadan.

$0.5 \mathrm{~g}$ of the extract was diluted with $10 \%$ DMSO (dimethyl sulfoxide) to concentrations of $50,25,12.5 \mathrm{and} 6.25 \mathrm{mg} / \mathrm{mL}$ using a two-fold dilution method. Inoculums were prepared in $5 \mathrm{~mL}$ Normal saline with 3-5 colonies of each bacterial strain. The inoculums were adjusted to $0.5 \mathrm{McF}$ arland standards for susceptibility testing [23]. The antibacterial activity of the extracts was determined in accordance with the standard agar-well diffusion method [24]. Muller-Hinton agar were prepared and poured into a Petri-dish, and allowed to solidify. Sterile swab sticks were used to swab the surface of the agar with the tested organisms. A sterile $6 \mathrm{~mm}$ cork borer was used to punch holes (i.e. 5 wells) in the inoculated agar. Four wells were filled with different concentrations of the extract while the fifth well was filled with DMSO (negative control) which was labeled accordingly. Tetracycline was placed in the middle as the positive control. The Petri-dishes were left on the work bench for 40 minutes for adequate diffusion of the extract [25] and then incubated at $37^{\circ} \mathrm{C}$ for 24 hours. Antibacterial activity of the extracts was determined by measurement of the zone of inhibition $(\mathrm{mm})$ against each test bacteria using a ruler. The experiment was carried out in triplicates and the mean values of the result were taken as antibacterial activity [26 27]. 


\section{Results and discussion}

\subsection{Phytochemical Screening}

Preliminary phytochemical investigation of the methanol extract of the antimalarial tea of $C$. aurantifolia (leaves and peel), P. guajava (leaves) and O.gratissimum (leaves) revealed the antimalaria tea extract is rich in phytochemicals. The tea contained tannins, flavonoids, saponins, glycoside, steroids, antraquinone, phlobatannins, and terpenoids. Some of these secondary metabolites were not detected in the individual plants, but the combination of these plants might have been the reason for the presence of these phytochemicals. A phytochemical study carried out by Pathan et al. [28] showed the absence of terpenoids in the leaves, tannins and flavonoids in the peels of $C$. aurantifolia. Also, Prasad et al. [29] also reported an absence of flavonoids, tannins, terpenoids, and saponins in the methanol extract of C. aurantifolia leaves. A study by Akinmoladun et al. [30] on the phytochemical constituents of methanol extract of 0 . gratissimum showed the absence of saponins and anthraquinones. Ayoola et al. [31] investigated the phytochemical constituents of P. guajava, anthraquinones and alkaloids were absent. Akinmoladun et al. [32] carried out a study on the phytochemical constituents of P. guajava, alkaloids and phlobatannins were not detected. These phytochemicals were all present in the combined tea extract. This may be as a result of some chemical reactions between compounds in the different plants. The result of the phytochemical screening shows that this combined mixture is rich in a wide variety of phytochemicals, hence, its use in herbal medicine.

\subsection{Antioxidant assay}

The percentage inhibition of DPPH radical by the methanol extracts of the antimalaria tea of citrus aurantifolia, Psidium guajava and Ocimum gratissimum is recorded in table 1 . The extract showed a negative percentage inhibition (-7\%) at the highest concentration of $1 \mathrm{mg} / \mathrm{ml}$, this could be as a result of an antagonistic effect between the various compounds present in the extracts [33]. while at the lowest concentration of $0.25 \mathrm{mg} / \mathrm{ml}$ the extract had a percentage inhibition of $62 \%$ which was almost similar to that of the standard antioxidant used at same concentration. This result is peculiar because the different plants have been observed to have good DPPH radical scavenging abilities, though that of lime peel and juice varies depending on the type and concentration of the flavonoid present [17,19, 34]. A likely explanation for this observation could be that, at high concentration the other compounds present in the mixture mask the effect of the active components, but as the concentration reduces it is possible that the interaction between the various compounds becomes negligible allowing the active components to exert their antioxidant abilities. This may not necessary be a bad thing because studies have revealed that at low or moderate levels free radicals exert some beneficial effects [35]. But it still stands to reason that too much consumption of them can become a double edged sword, since the over generation of reactive oxygen species in the body results in oxidative stress which can lead to cell damage [36].

Table 1 Percentage inhibition of DPPH radical of methanol extract of antimalaria tea

\begin{tabular}{llll}
\hline Concentration $\mathbf{~ m g} / \mathbf{m l}$ & AMT & BHA & VIT C \\
\hline 1.0 & $-7 \%$ & $71 \%$ & $94.4 \%$ \\
0.5 & $39 \%$ & $71 \%$ & $93.4 \%$ \\
0.25 & $62 \%$ & $69 \%$ & $92.4 \%$ \\
\hline \multicolumn{2}{r}{ Key: AMT - Antimalaria Tea. BHA - Butylated hydroxyl anisole. VIT C - Vitamin C. }
\end{tabular}

\subsection{Antibacterial Activity}

The antibacterial activities of the methanol extract of the antimalarial tea against a total of five bacterial are shown in Table 2. When the agar diffusion method was used, the extracts caused different inhibition zones, and had a varied antibacterial effect on the bacterial strains. K pneumonia and $P$ aeruginosa were resistant to the extracts because at all concentration levels $(50,25,12.5$ and 6.25) they showed no zone of inhibition. All five bacterial showed no zone of inhibition at concentrations of 12.5 and $6.25 \mathrm{mg} / \mathrm{ml}$. The extract at concentrations of 50 and $25 \mathrm{mg} / \mathrm{ml} \mathrm{was} \mathrm{able} \mathrm{to}$ inhibit the growth of $S$. aureus to a level that was comparable to that of the standard tetracycline. Studies have shown that the individual plants extract of Citrus aurantifolia, Psidium guajava and Ocimum gratissimum has higher antibacterial activity as compared with that of the combined plants. Pathan et al. [28] reported the antibacterial effect of $C$. aurantifolia on the bacteria's studied in this work and they showed lower zones of inhibition. Qa'dan et al. [37] carried out a research of the antibacterial activity of $P$. guajava on $S$. aureus and the observed zones of inhibition were lower than that recorded in this study while the plant extract was not sensitive to E. coli and P. aeruginosa. 
Table 2 Zones of inhibition (in $\mathrm{mm}$ ) of antimalaria tea extract

\begin{tabular}{llllll}
\hline $\begin{array}{l}\text { Concentration of } \\
\text { sample } \\
\text { (mg/mL) }\end{array}$ & $\begin{array}{l}\text { Klebsiella } \\
\text { pneumonia } \\
\text { (EI) }\end{array}$ & $\begin{array}{l}\text { Klebsiella } \\
\text { pneumonia } \\
\text { (CI) }\end{array}$ & $\begin{array}{l}\text { Staphylococcus } \\
\text { aureus }\end{array}$ & $\begin{array}{l}\text { Pseudomonas } \\
\text { aeruginosa }\end{array}$ & $\begin{array}{l}\text { Escherichia } \\
\text { coli }\end{array}$ \\
\hline 50 & 8 & - & 12 & - & 10 \\
25 & 8 & - & 10 & - & 9 \\
12.5 & - & - & - & - & - \\
6.25 & - & - & - & - & - \\
Positive control & 10 & 10 & 11 & 10 & 12 \\
$(30 \mathrm{mg} / \mathrm{mL})$ & & & - & - & - \\
Negative control & - & & - & - \\
\hline \multicolumn{2}{l}{ Key: EI - Environmental isolate, CI - Clinical isolate, Positive control - Tetracycline, Negative control - Dimethyl sulphoxide (DMSO). }
\end{tabular}

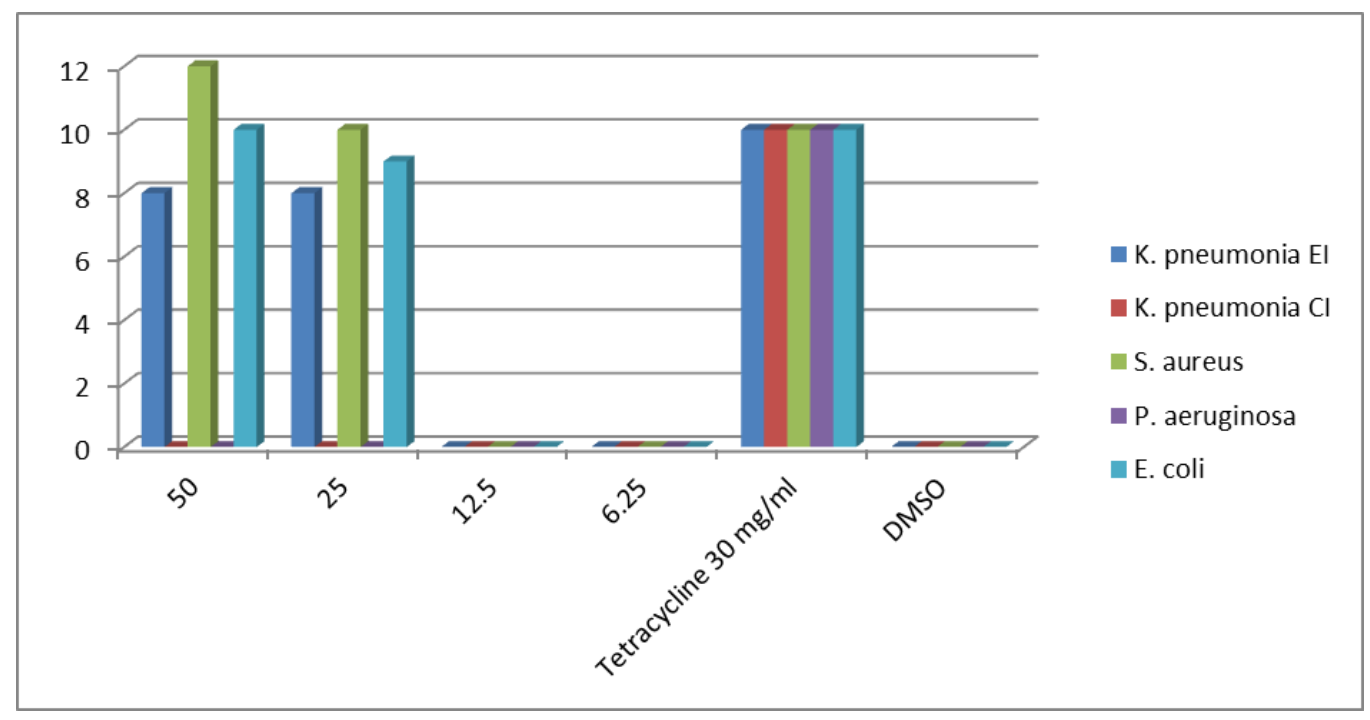

Figure 1 Graphical representation of antibacterial activity of the antimalaria tea extract

\section{Conclusion}

The antimalaria tea of citrus aurantifolia, leaves and peels, Psidium guajava leaves and Ocimum gratifolia is a recipe that is rich in phytochemical, and could be useful in inhibiting the growth of staphylococcus aureus in the body. But at high concentration the antimalaria tea has no ability to scavenge free radicals in the body, so an excessive consumption of the tea is discouraged because at high concentration the tea could contribute to the generation of free radical in the body which could result in cancer, cardiovascular disease or premature ageing.

\section{Compliance with ethical standards}

\section{Acknowledgments}

The authors would like to acknowledge the support of Mr. Michael Gabriel Ibok of the Department of Chemistry, University of Ibadan for the provision of the standards used for the antioxidant assay.

\section{Disclosure of conflict of interest}

The authors declare that there is no conflict of interest. 


\section{References}

[1] Kozarsky PE and Lobel HO. (1994). Antimalaria agents: are we running out of options? Current Opinion in Infectious Diseases, 7, 701.

[2] Odugbemi TO, Akinsulire OR, Aibinu IE and Fabeku PO. (2007). Medicinal plants useful for malaria therapy in Okeigbo, Ondo State, Southwest Nigeria. African Journal of Traditional Complementary and Alternative Medicines, 4, 191-198.

[3] Burkinwa H and Orton LC. (2005). Aresunate plus mefloquine versus mefloquin for treating uncomplicated malaria. Cochrane Database of Systematic Review, CD004531,0ctober 19.

[4] Afolayan FID, Adegbolagun OM, Irungu B, Kangethe L, Orwa J and Anumudu C. (2016). Antimalaria actions of Lawsonia inermis, Tithonia divesifolia and Chromolaena odorata in combination. Journal of Ethnopharmacology, $191,188-194$.

[5] Idowu ET, Ajaegbu HCN, Omolayo AI, Aina 00 and Otubanjo OA. (2015). Invivo anti-plasmodial ativitives and toxic impacts of lime extracts of a combination of Picralima nitida, Alstonia boonei and Gongronema latifolium in mice infected with chloroquine-sensitive Plasmodium berghei. African. Health Sciences, 15(4), 1262-1270.

[6] Tomchinsky B, Meng LC, Kinupp VF, Hidalgo A and Chaves F. (2017). Ethnobotanical study of antimalaria plants in the middle region of the Negro River, Amazonas, Brazil. Acta Amazonica, 47(3), 203-212.

[7] Barliana MI, Suraadji EW, Abdulah R, Diantini A, Hatabu T, Nakajima-Shimada J and Koyama H. (2014). Antiplasmodial properties of kaempferol-3-o-rhamnoside isolated from the leaves of Schima wallichii against Chloroquine-resistant Plasmodium falciparum. Biomedical Reports, 2, 579-583.

[8] Iwu MM. (2014). Handbook of African medicinal plants Second edition. CRC press Taylor and Francis group. USA, 347.

[9] Aibinu I, Adenipekun T, Adelowotan T, Ogunsanya T and Odugbemi T. (2007). Evaluation of the antimicrobial properties of different parts of Citrus aurantifolia (lime fruit) as used locally. African Journal of Traditional Complementry and Alternative Medicine, 4(2), 185-190.

[10] Adegoke SA, Oyelami OA, Olatunya OS and Adeyemi IA. (2011). Effects of lime juice on malaria parasites clearance. Phytotherapy Research, 25(10), 1547-1550.

[11] Rios CD, Salazar CR, Cardona C, Victoria K and Torres MG. (1977). Frutales. In Instituto Colombiano Agropecuario. Manual de asistencia tenica 2nd ed, vol 4. Columbia, 221-248.

[12] Gutierrez R, Mitchell S and Solis R. (2008). Psidium guajava: A review of its traditional uses, phytochemistry and pharmacology. Journal of Ethnopharmacology, 117, 1-27.

[13] Aguiyi JC, Obi CI, Gyang SS and Igweh AC. (2000). Hypoglycemic activity of Ocimum gratissimum in rats. Fitoterapia, 71, 444-446.

[14] Agnaniet H, Arguillet J, Bessieve J and Menut C. (2005). Aromatic plants of tropical Central Africa. Part XLVIL Chemical and Biological investigation of essential oil of Ocimum species from Gabon. Journal of Essential Oil Research,17(4), 466-470.

[15] Ponce M, Navarro A, Martinez G and Alvarez C. (1994). In vitro effect against Giardia of 14 plant extracts. Revista de Investigacion Clinica, 46, 343-347.

[16] Nundkumar N and Ojewole J. (2002). Studies on the antiplasmodial properties of some South African medicinal plants used as antimalarial remedies in Zulu folk medicine. Methods and Findings in Experimental and Clinical Pharmacology, 24, 397-401.

[17] Qian H and Nihorimbere V. (2004). Antioxidant power of phytochemicals from Psidium guajava leaf. Journal of Zhejiang University Science B, 5(6), 676-683.

[18] Awah F and Verla AW. (2010). Antioxidant activity, nitric oxide scavenging activity and phenolic contents of Ocimum gratissimum leaf extract. Journal of Medicinal Plants Research, 4(24), 2479-2487.

[19] Boshtam M, Moshtaghian J, Naderi G, Asgary S and Nayeri H. (2011). Antioxidant effects of Citrus aurantifolia (Christm) juice and peel extract on LDL oxidation. Journal of Resource and Medical Science, 16(7), 951-955.

[20] Harbone JB. (1973). Phytochemical methods. Chapman and Hall ltd, London, 49-183. 
[21] Mensor LI, Menezes FS, Leitao GG, Reis AS, Santos TC, Coube CS and Leita SG. (2001). Screening of Brazilian plant extracts for antioxidant activity by the use of DPPH free radical method. Phytotherapy Research, 15, 127-130.

[22] Oghenejoboh UM and Nkop JN. (2018). Chemical Composition, Cytotoxicity and Antioxidant Activities of Essential Oils of Parquetina nigrescens (afz.) Bullock from Ibadan, Nigeria. The pharmaceutical and Chemical Journal, 5(5), 99-104.

[23] National Committee for Clinical Laboratory Standards. (2001). Performance standards for antimicrobial susceptibility testing. Eleventh informational supplement M100-S11. National Committee for Clinical Laboratory Standards. USA,

[24] Irobi O, Young M and Anderson W. (1994). Antimicrobial activity of Annato (Bixa orella) extract. International Journal of Pharmacognosy, 34, 87-90.

[25] Esimone C, Adikwu M and Okonta J. (1998). Preliminary antimicrobial screening of ethanolic extract from the lichen Usnea subfloridans (L). Journal of Pharmaceutical Research and Development, 3(2), 99-101.

[26] Abayomi S. (1982). The state of medicinal plants research in Nigeria. University of Ife Press. Nigeria.

[27] Junaid S, Olabode A, Onwudiri F, Okwori A and Agina S. (2006). The antimicrobial properties of Ocimum gratissimum extract on some gastrointestinal isolates. African Journal of Biotechnology, 5(22), 2315-2321.

[28] Pathan RK, Gali PR, Pathan P, Gowtham T and Pasupuleti S. (2012). In vitro Antimicrobial Activity of Citrus aurantifolia and its Phytochemical Screening. Asian Pacific Journal of Tropical Disease, 2(S1), 328-331.

[29] Prasad M, Balamurugan P and Rajkumar R. (2014). Comparative Phytochemical Analysis of Rutaceae Family (Citrus Species) Extracts. International Journal of Scientific Research, 3(4), 148-150.

[30] Akinmoladun A, Ibukun E, Afor E, Obuotor E and Farombi E. (2007). Phytochemical constituent and antioxidant activity of extract from the leaves of Ocimum gratissimum. Scientific Research and Essay, 2(5), 163-166.

[31] Ayoola G, Coker H, Adesegun S, Adepoju-Bello A, Obaweya K and Ezennia E. (2008). Phytochemical Screening and Antioxidant Activities of Some Selected Medicinal Plants Used for Malaria Therapy in Southwestern Nigeria. Tropical Journal of Pharmaceutical Research, 7(3), 1019-1024.

[32] Akinmoladun A, Obuotor E and Farombi E. (2010). Evaluation of Antioxidant and Free Radical Scavenging Capacities of Some Nigerian Indigenous Medicinal Plants. Journal of Medicinal Food, 13(2), 444-451.

[33] Caesar LF and Cech NB. (2019). Synergy and antagonism in natural product extracts: when $1+1$ does not equal 2. Natural Product Reports, 36, 809-888.

[34] Njoku OU, Joshua PE, Agu CV and Dim NC. (2011). Antioxidant property of Ocimum gratissimum (scent leaf). New York Science Journal, 4(5), 98-103.

[35] Pham-Huy LA, He H and Pham-Huy C. (2008). Free radicals, antioxidants in disease and health. International Journal of Biomedical Science, 4(2), 89-96.

[36] Salehi B, Marlorell M, Arbiser JL, Sureda A, Martins N, Maurya PK, Sharifi-Rad M, Kumar P and Sharifi-Rad J. (2018). Antioxidants: positive or negative actors? Biomolecules, 8(4), 124.

[37] Qadan F, Thewaini A, Ali D, Afifi R, Elkhawad A and Matalka K. (2005). The antimicrobial activities of Psidium guajava and Juglans regia leaf extracts to acne-developing organism. The American Journal of Chinese Medicine, 33(2), 97-204.

\section{How to cite this article}

Oghenejoboh U, Adeniyi-Akee M, Ashioma M, Ogundairo SK and Olowolagba AM. (2020). Phytochemical, antibacterial and free radical scavenging activities of a local antimalaria tea from Nigeria. GSC Biological and Pharmaceutical Sciences, $7(2), 21-26$. 